\title{
Membumikan penyusunan laporan keuangan industri perkebunan kelapa sawit menggunakan pendekatan aset biologis berdasarkan PSAK 69
}

\author{
Emrinaldi Nur DP*, Rusli, dan Eka Hariyani \\ Universitas Riau \\ * enurdp@yahoo.co.uk
}

\begin{abstract}
Abstrak. Usaha Mikro Kecil dan Menengah (UMKM) telah menjadi primadona pertumbuhan ekonomi Indonesia. Besaran kontribusi UMKM terhadap GDP di tahun 2018 mencapai 60,34\%. Kontribusi tersebut mendorong pemerintah lebih mengembangkan UMKM, termasuk aspek manajemennya berupa penyusunan laporan keuangan. Keberadaan daerah perdagangan bebas, juga menuntut semua industri menyajikan laporan keuangannya menggunakan standar internasional, termasuk pada industri perkebunan kelapa sawit baik besar maupun kecil seperti UMKM. Oleh karenanya IAI telah menerbitkan PSAK 69 tentang agrikultur yang di adopsi dari IAS 41 menggunakan pendekatan aset biologis. Namun PSAK tersebut tidak menunjukkan penerapannya pada industri ini, mengingat luasnya cakupan agrikultur. Melalui hibah riset nasional di tahun 2018, pelaksana pengabdian telah melakukan kajian, dan menghasilkan petunjuk teknis pelaporan tersebut. Kegiatan pengabdian ini dilakukan untuk mendiseminasi hasil temuan tersebut sekaligus menerapkannya pada UMKM kelapa sawit. Metode yang digunakan adalah survey kemampuan penyusunan laporan keuangan umum, dilanjutkan dengan diseminasi penyusunan laporan keuangan menggunakan aset biologis, pendampingan dan diakhir dengan evaluasi atas diseminasi dan pendampingan yang dilakukan. Kegiatan pengabdian dilakukan pada Kepenghuluan Mukti Jaya Kecamatan Rimba Melintang Kabupaten Rokan Hilir. Hasil yang diperoleh menunjukkan adanya peningkatan pemahaman akan arti penting laporan keuangan secara umum dan dihasilnya laporan keuangan sederhana untuk industri kelapa sawit pada UMKM daerah sasaran.
\end{abstract}

Kata kunci: UMKM; PSAK 69; IAS 41; aset biologis; kelapa sawit

\begin{abstract}
Micro, Small and Medium Enterprises (MSMEs) have become the belle of Indonesia's economic growth. The contribution of MSMEs to GDP in 2018 reached 60.34\%. This contribution encouraged the government to further develop MSMEs, including its management aspects such as preparing financial statements. The existence of free trade areas also requires all industries to present their financial reports using international standards, including palm oil industry both large and small, such as MSMEs. Therefore, IAI has issued PSAK 69 concerning agriculture which adopted from IAS 41 using a biological asset approach. However, the PSAK does not show its application to this industry, given the broad scope of agriculture. Through national research grants in 2018, researcher have carried out studies, and produced technical reporting guidelines. At this time, we have already disseminated the findings to oil palm MSMEs. Survey and dissemination for preparation financial reporting used to this activity. This activity were carried out at Kepenghuluan Mukti Jaya, Rimba Melintang District, Rokan Hilir Regency. The results showed that an increasing of understanding to the importance of financial statements in general and the results of financial reports for the oil palm industry in the MSMEs target area.
\end{abstract}

Keywords: MSMEs; PSAK 69; IAS 41; biological asset; palm oil

To cite this article: Nur DP, E., Rusli, \& E. Hariyani. 2019. Membumikan penyusunan laporan keuangan industri perkebunan kelapa sawit menggunakan pendekatan aset biologis berdasarkan PSAK 69. Unri Conference Series: Community Engagement 1: 168-179. https://doi.org/10.31258/unricsce.1.168-179

(C) 2019 Authors

Peer-review under responsibility of the organizing committee of Seminar Nasional Pemberdayaan Masyarakat 2019 


\section{PENDAHULUAN}

Perkembangan Usaha Mikro Kecil dan Menengah (UMKM) selama lima tahun terakhir terus menunjukkan keutamaannya sebagai kontributor Poduk Domestik Bruto (PDB) yang signifikan. Data Kadin (2018), data kantor Staf Presiden (2018) dan data Kementrian Perindustrian dan Kementrian Koperasi dan UMKM di tahun 2018 menunjukkan bahwa UMKM berkontribusi $61 \%$ terhadap PDB keseluruhan. Nilai tersebut terdiri dari usaha mikro $30,3 \%$, usaha kecil 12,8\%, dan usaha menengah 14,5\%. Besarnya kontribusi UMKM tidak hanya pada PDRB, namun juga pada jumlah tenaga kerja yang terlibat. Sepanjang lima tahun terakhir peningkatan jumlah tenaga kerja pada sektor UMKM sebesar 97,22\% yang sebelumnya 96,99\%.

Keberpihakan pemerintah pada pengembangan UMKM ditunjukkan dengan diterapkannya UU No.20 Tahun 2008 tentang Usaha Mikro, Kecil dan Menengah serta PP No.17 Tahun 2013. Namun begitu pemerintah juga mengakui masih ada kelemahan yang terdapat dalam operasional UMKM di Indonesia. Kelemahan tersebut berupa rendahnya produktivitas, rendahnya nilai tambah, dan rendahnya kualitas produk serta rendahnya kemampuan dalam mengelola aspek manajerial UMKM tersebut (Tambunan, 2002). Aspek manajerial yang dimaksud adalah pengelolaan dan pelaporan keuangan. Bentuk lain keberpihakan pemerintah terhadap UMKM ditunjukkan dengan semakin besarnya alokasi KUR (Kredit Usaha Rakyat), dan kredit dari Lembaga Pengelola Dana Bergulir (LPDB- KUMKM). Kedua bentuk kredit ini pada dasarnya membutuhkan administrasi pelaporan keuangan yang dilakukan UMKM sebagai bagian usulan dan pertanggungjawaban,

Laporan keuangan merupakan informasi penting yang menyajikan posisi harta, hutang dan modal serta hasil operasi perusahaan (Emrinaldi, 2003). Melalui laporan keuangan pemilik dan pihak-pihak yang berkaitan dengan badan usaha tersebut dapat mengetahui perkembangan bisnis perusahaan serta merencanakan kegiatan bisnis selanjutnya (Munawir, 2010). Oleh karenanya penting artinya bagi badan usaha memiliki kemampuan dalam mengelola keuangan dan menyusun laporan keuangan tersebut.

Semakin tidak jelasnya batas-batas negara dalam sistem perdagangan dan ekonomi antar negara (Ala, dkk., 2013), seperti diberlakukannya ACFTA 2010, AFTA 2015 dan MEA di tahun 2015, serta APEC 2020, telah melahirkan konsekwensi berupa perdagangan dan investasi lintas negara. Oleh karenanya tuntutan informasi keuangan pada pelaporan keuangan, agar bisa dipahami oleh berbagai pihak baik dalam dan luar negeri telah menjadi keharusan.

Ikatan Akuntan Indonesia (IAI) sebagai bagian dari International Federation of Accountants bersama dengan pemerintah di tahun 2008 mencanangkan penggunaan Standar Internasional atau yang lebih dikenal dengan IFRS (Unternational Financial Reporting Standards). Tahun 2006 hingga 2008 merupakan tahapan awal konvergensi Standar Akuntansi Keuangan (SAK) dalam bentuk Pernyataan Standar Akuntansi Keuangan (PSAK) ke Standar Akuntansi Internasional (IAS).

PSAK No. 16 tentang Aset Tetap dan Aset Lainnya disyahkan IAI pada tanggal 29 Mei 2007 yang selanjutnya di revisi pada tanggal 29 November 2011 merupakan salah satu produk IAI yang didasarkan pada IAS. Pada PSAK No.16 tersebut diatur bagaimana mengakui, mencatat dan menilai Aset tetap dan Aset lainnya. Salah satu Aset lainnya yang diatur adalah Aset Biologis berupa agrikultur. Namun begitu pengaturan Aset Biologis pada pertengahan tahun 2015 diatur pada PSAK tersendiri, yaitu PSKA No. 69 tentang Agrikultur dan disahkan pada Desember 2015. PSAK 69 ini efektif 1 Januari 2018. Namun mengingat banyaknya jenis agrikultur ini, belum ada panduan secara spesifik yang memberikan arahan bagaimana penerapannya pada industri agrikultur tertentu, seperti kelapa sawit. Emrinaldi, dkk. (2018) dalam penelitian terapannya mencoba meneliti kemungkinan proses transformasi laporan keuangan dan menghasilkan panduan penyusunan laporan keuangan dengan pendekatan asset biologis untuk industri kelapa sawit tersebut.

\section{MASALAH}

Signifikansinya perubahan dalam perlakuan aset biologis tidak hanya mengarah kepada badan usaha besar, namun juga UMKM. Perubahan perlakuan tersebut menyebabkan semua badan usaha yang bergerak di bidang agrikultur seperti kelapa sawit diminta untuk melakukan transformasi dalam penyusunan laporan keuangan mereka. Namun yang menjadi perhatian adalah bagaimana kesiapan UMKM tersebut terutama petani yang bergerak pada indusri tersebut. Oleh karenanya sangat dibutuhkan pengenalan sekaligus pendampingan bagi UMKM dan petani tersebut.

Indonesia merupakan Negara dengan areal dan penghasil CPO terbesar di dunia (14,03 juta Ha/47,6 juta ton per), sementara Riau merupakan propinsi dengan areal dan penghasil terbesar di Indonesia $(2,4$ juta $\mathrm{Ha} / 32,02$ juta ton). Luasnya areal sawit di Riau sangat tidak memungkinkan untuk dapat mensosialisasikan penyusunan laporan keuangan industry kelapa sawit menggunakan pendekatan asset biologis pada UMKM di 
Riau. Oleh karenanya dalam kegiatan pengabdian ini, wilayah sasaran yang menjadi target adalah Kepenghuluan Mukti Jaya pada Kecamatan Rimba Melintang, Kabupaten Rokan Hilir. Daerah ini mayoritas penduduknya menjadi petani kelapa sawit ataupun menjadi buruh tani pada bidang industri kelapa sawit. Dengan jumlah penduduk sebanyak 3.430 jiwa dan 2.091 jiwa diantaranya berada pada usia 19-56 tahun, dengan pekerjaan mayoritas sebagai petani sawit, maka daerah ini dianggap cocok untuk dijadikan daerah sasaran untuk melakukan kegiatan pengenalan dan pendampingan dalam penyusunan laporan keuangan dengan menggunakan pendekatan aset biologis berdasarkan PSAK 69.

Evaluasi awal yang dilakukan menunjukkan bahwa hampir seluruh petani sawit tidak mengenal arti pelaporan keuangan yang baku. Pencatatan hanya dilakukan oleh beberapa warga yang umumnya berpendidikan lebih tinggi, namun tidak dalam bentuk laporan keuangan. Pencatatan dilakukan untuk menghitung penjualan pada saat pengumpulan TBS. Oleh karenanya pengenalan laporan keuangan dasar sebelum pengenalan penyusunan laporan keuangan menggunakan pendekatan asset biologis menjadi penting artinya. Sehingga diharapkan melalui kegiatan ini akan mampu meningkatkan pengembangan UMKM dari aspek manajerial, terutama dalam penyusunan laporan keuangan mereka.

\section{METODE}

Lokasi dan Waktu Pengabdian Kegiatan Pengabdian Kepada Masyarakat ini dilakukan efektif Dua bulan yang dimulai pada Bulan Mei 2019 di Kepenghuluan Mukti Jaya, Kecamatan Rimba Melintang Kabupaten Rokan Hilir. Sementara Objek Kegiatan Pengabdian adalah UMKM ataupun Masyarakat Petani Kelapa Sawit pada daerah yang menjadi lokasi kegiatan Pengabdian dan bersedia untuk kegiatan pengenalan dan pendampingan penyusunan laporan keuangan industri kelapa sawit dengan menggunakan pendekatan aset biologis berdasarkan PSAK 69.

Teknik dan Metode Pengabdian yang dilakukan guna mencapai sasaran pengabdian di atas, tim menempuh beberapa tahapan:

1. Evaluasi awal wilayah pengabdian guna mendapatkan UMKM dan masyarakat yang bersedia untuk ikut dalam kegiatan pengabdian ini, melalui survey lapangan.

2. Memberikan pengenalan manfaat pelaporan keuangan bagi UMKM tersebut dengan menggunakan mekanisme sosialisasi atau presentasi

3. Menanyakan kembali kepada peserta yang ikut dalam pengenalan manfaat pelaporan keuangan tersebut untuk terlibat kembali dalam proses pendampingan penyusunan laporan keuangan pada industri kelapa sawit dengan menggunakan pendekatan aset biologis, dengan menggunakan mekanisme wawancara informasl. Jika bersedia dibuatkan dokumen kemitraan pengabdian.

4. Memberikan pelatihan dan pendapingan penyusunan laporan keuangan, baik secara langsung maupun melalui media komunikasi dengan cara pembekalan dan FGD.

5. Mengevaluasi hasil pengenalan dan pendampingan yang telah dilakukan guna mengevaluasi kesuksesan kegiatan pengabdian yang telah dilakukan dengan menggunakan perhitungan statistik sederhana.

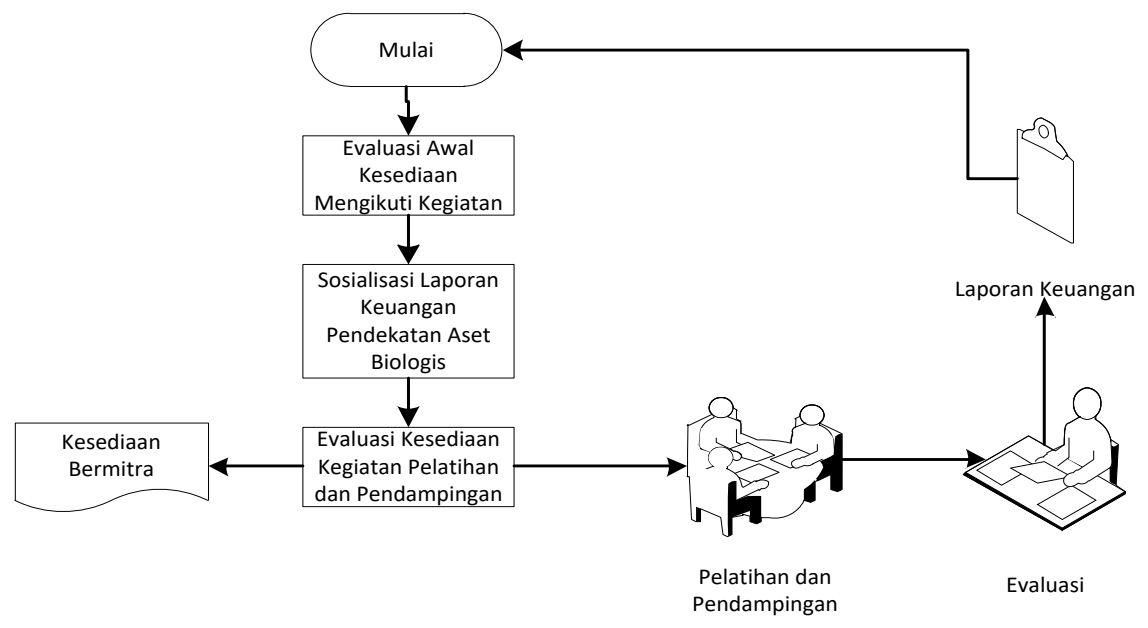

Gambar 1. Proses Kegiatan Pengabdian 


\section{PEMBAHASAN}

Konvergensi IFRS Perkembangan ekonomi Indonesia dan ekonomi dunia yang semakin global dengan pembentukan berbagai daerah perdagangan bebas (free trade zone) serta keanggotaan Ikatan Akuntan Indonesia (IAI) yang menjadi bagian dari Ikatan Akuntan Dunia atau The International Federation of Accountant (IFAC) telah mendorong IAI bersama kementrian keuangan untuk mengadopsi Standar Pelaporan Keuangan Internasional atau International Financial Reporting Standards (IFRS). Pengukuhan untuk melakukan adopsi tersebut didasarkan pada kebijakan Komite Standar Akuntansi Keuangan untuk menggunakan Standar Akuntansi Internasional International Accounting Standard) dalam menyususn Standar Akuntansi Keuangan (SAK) di Indonesia di tahun 1994. Kondisi tersebut juga didukung dengan diskusi IAI bersama dengan Dirjen Pembinaan Akuntan dan Jasa Penilai mengundang DPN-IAI, kompartemen IAI, DSAK-IAI, DSPAP-IAI KAP, Bapepam, KSAPPD berkenaan dengan kesiapan profesi akuntan melakukan konvergensi standar yang berlaku internasional di Pertengahan Agustus 2004. Konsekwensi dari konvergensi tersebut adalah diadopsinya IAS 41 yang di sesuaikan menjadi PSAK 69.

PSAK 69 memuat pengaturan tentang perlakuan akuntansi untuk asset agrikultur menggunakan pendekatan asset biologis. Aset bilogis dalam IAS 41 didefenisikan sebagai tumbuhan dan hewan yang hidup (Biological asset is a living animal or plani). Aset biologis adalah aset yang unik, karena mengalami transformasi pertumbuhan bahkan setelah aset biologis menghasilkan sebuah output. Transformasi yang terjadi pada aset biologis terdiri dari proses pertumbuhan, degenerasi, produksi dan prokreasi yang dapat menyebabkan berbagai perubahan secara kualitatif dan kuantitatif dalam kehidupan aset yang berupa tumbuhan atau hewan tersebut. Aset biologis dapat menghasilkan aset baru yang terwujud dalam agricultural produce atau berupa tambahan aset biologis dalam kelas yang sama.

Seperti yang disampaikan di atas bahwa agrikultur dalam hal ini bukan hanya hewan namun juga tumbuhan yang di produksi guna memperoleh manfaat di masa depan. Oleh karenanya variansi pada asset biologis ini sangatlah banyak dan membutuhkan perlakuan yang berbeda beda, sementara PSAK 69 tidak secara spesifikan mengarahkan agrikultur asset tersebut. Pada kegiatan pengabdian ini yang menjadi target adalah asset berupa tumbuhan dalam hal ini kelapa sawit. Kelapa sawit dipilih mengingat Indonesia sebagai Negara dengan Produksi sawit terbesar didunia dan Riau sebagai Propinsi dengan luas lahan terbesar di Indonesia. Oleh karena itu menjadi penting artinya pembahasan mengenai kelapa sawit tersebut.

Penelitian yang dilakukan Emrinaldi, dkk. (2018) telah melahirkan panduan teknis penyusunan laporan keuangan industry kelapa sawit tersebut dengan pendekatan asset biologis. Sehingga kegiatan pengabdian ini merupakan lanjutan dari kegiatan penelitian terapan yang telah dilakukan sebelumnya. Namun begitu untuk memahami penyusunan Laporan Keuangan dengan menggunakan pendekatan asset biologis juga membutuhkan pengetahuan akan arti laporan keuangan tersebut sesungguhnya. Laporan keuangan dapat diartikan sebagai laporan yang menggambarkan posisi harta, hutang, modal dan hasil operasi usaha selama satu periode tertentu. Laporan keuangan tersebut terbagi dalam lima jenis laporan, yaitu laporan posisi keuangan, laporan perubahan modal, laporan laba dan rugi usaha, laporan arus kas dan catatan atas laporan keuangan.

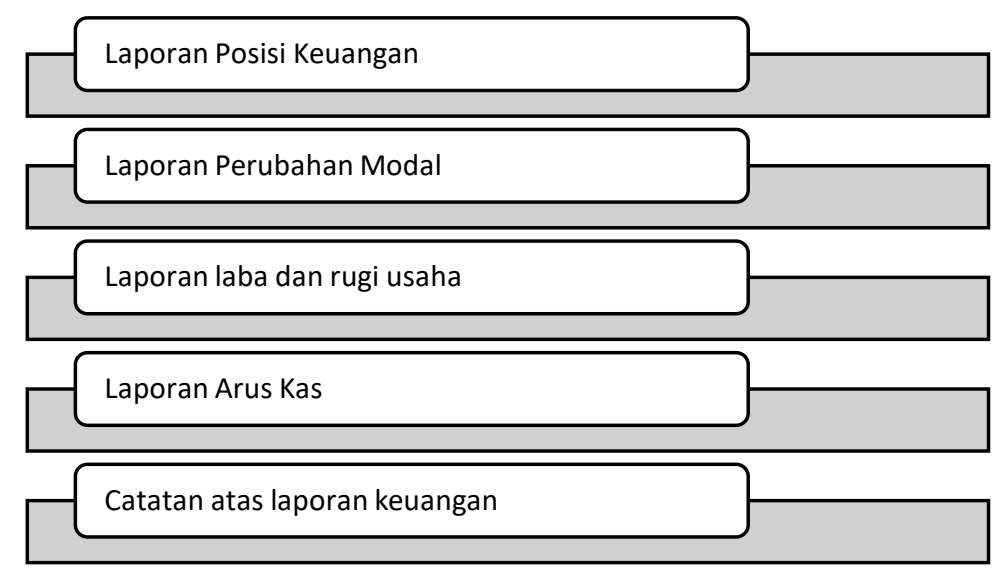

Gambar 2. Jenis-Jenis Laporan Keuangan 
Aset biologis memiliki konsekwensi pada semua jenis laporan tersebut. Sehingga semua jenis laporan tersebut juga butuh dikuasai oleh UMKM yang akan menerapkan laporan keuangan agrikultur tersebut.

Kelapa sawit merupakan tanaman yang bertransformasi dimulai dari proses pembibitan, pegembangan buah pasir dan produksi maksimal. Inilah yang selanjutnya harus mendapatkan perlakuan sebagai asset biologis berdasarkan PSAK 69 tersebut.

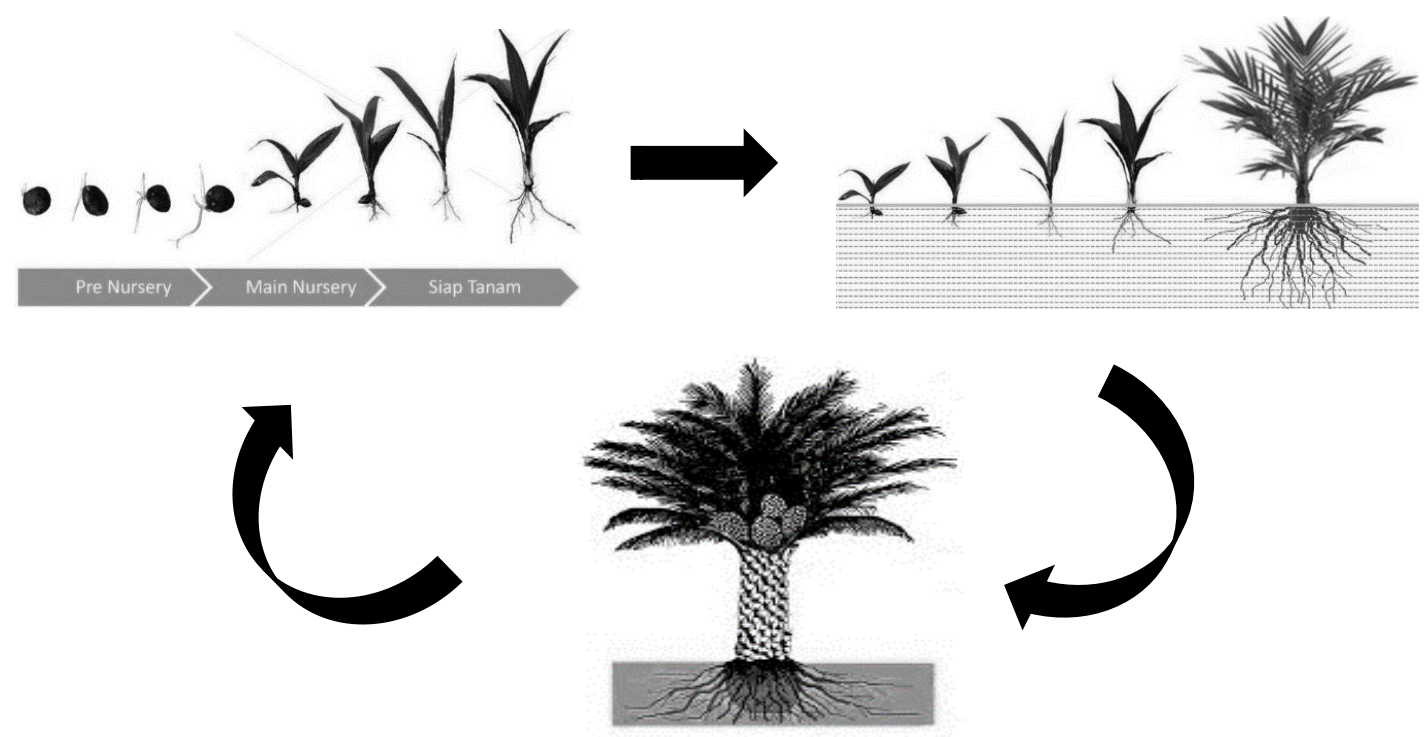

Gambar 3. Gambar Tahapan Transformasi Kelapa Sawit

Secara ringkas, tahapan transformasi kelapa sawit di awali dari bibit berupa buah sawit yang selanjutya disemai untuk dijadikan bibit sawit. Setelah bibit sawit berumur 3-4 bulan, bibit sawit dipindahkan ke lahan penanaman yang lebih luas yang telah lebih dahulu dipersiapkan. Selanjutnya tanaman sawit melalui proses perawatan berupa penyiangan, pemupukan dan penyiraman menjadi tanaman yang belajar berbuah yang dikenal sebagai buah pasir yang biasanya sudah mulai dari umur 3-5 tahun. Pada tahun ke 6 kelapa sawit telah mulai berbuah sempurna menghasilkan TBS, dan akan berhenti pada usia 25 tahun. Tahapan berikutnya kembali pada proses awal berupa penanaman kembali tanaman muda hasil pembibitan. Proses ini lah yang selanjutnya mendapat perlakuan sebagai asset biologis. Namun begitu karena petani sawit atau UMKM sawit ini tidak hanya menanam dan memelihara hingga menghasilkan, namun juga memiliki asset, hutang, modal dan juga pendapatan serta biaya yang dikeluarkan dalam memproses kelapa sawit hingga akhir masa panen, maka transaksi pendukung lainnya juga tidak dapat dilepaskan dari akuntansi asset biologis tersebut.

Berdasarkan evaluasi awal atas kesediaan untuk mengikuti sosialisasi pelaporan keuangan pada industr kelapa sawit terdapat 30 orang peserta yang bersedia dan hadir pada kegiatan sosialisasi pelaporan keuangan industri kelapa sawit. Jumlah 30 orang tersebut diakui belum mampu mewakili seluruh petani ataupun umkm yang bergerak pada perkebunan kelapa sawit pada daerah objek pengabdian. Namun keterbatasan tempat, waktu dan pendanaan juga keharusan petani yang terlibat untuk memiliki keinginan menguasai pelaporan keuangan tersebut, maka jumlah ini dianggap sudah memadai. Pengenalan pelaporan keuangan kelapa sawit ini hanya satu kali. Pengenalan yang dilakukan masih bersifat umum laporan keuangan dan pendekatan asset biologis. Ini dimaksudkan untuk memberi ketertarikan kepada peserta agar mau terlibat pada tahapan kegiatan berikutnya yang lebih intensif.

Pengenalan dilakukan terhadap:

1. Jenis laporan keuangan

2. Tujuan pelaporan keuangan

3. Kaitan laporan keuangan dan industri kelapa sawit

4. Pendekatan asset biologis dengan PSAK 69

5. Jenis asset keuangan dalam kategori FVTL, HTM, LR dan AFS.

6. Pengelompokkan asset, berupa asset lancar dan asset tidak lancar.

7. Akuntansi liabilitas dan ekuitas

8. Akuntansi pendapatan dan beban

9. Penyajian laporan keuangan 
Pada asset lancar terdapat akun yang berkaitan langsung dengan industry kelapa sawit, yaitu persediaan, berupa persediaan hasi tanaman, dalam hal ini adalah TBS dan bibit kelapa sawit jika untuk dijual. Persediaan lainnya adalah persediaan bahan baku dan persediaan pelengkap berupa pupuk, obat-obatan tanaman (pestisida dan sebagainya), suku cadang (yang bukan merupakan suku cadang utama mesin tertentu); bahan bakar; lainlain. Dalam hal terdapat adanya produk sampingan berupa cangkang kelapa sawit, nilai penjualan cangkah tidak dapat mengurangi biaya perolehan persediaan namun menjadi pendapatan non usaha.

Pada asset tidak lancar terdapat perkiraan piutang pengembangan perkebunan rakyat, jika UMKM memberikan bantuan kepada UMKM lainnya baik berupa bibit, sara produksi ataupun permodalan. Selain piutang di atas juga terdapat investasi jangka panjang yang diklasifikasi sebagai asset keuangan HTM dan investasi pada entitas lain yang diklasifikasi sebagai asset keuangan AFS. Aset lainnya adalah asset tanaman semusim, yang merupakan bibit tanaman yang akan ditanam selanjutnya.

Beberapa perlakuan pada aset tanaman semusim:

1. Biaya perolehan diakui jika memenuhi dua syarat, yaitu:

a. Adanya kemungkinan besar manfaat ekonomi yang akan mengalir ke entitas'

b. Dapat diukur dengan andal.

2. Biaya perolehan awal aset tanaman semusim antara lain:

a. Biaya yang diakui sebagai bagian dari pembibitan, yaitu:

1) Biaya input. Harga perolehan bibit dan biaya lainnya yang dikeluarkan entitas sampai dengan bibit siap tanam.

2) Biaya proses. Biaya-biaya yang dikeluarkan setelah biaya input sampai menjadi bibit tanaman berikutnya yang terdiri dari:

a) Biaya tenaga kerja langsung diunit/kebun untuk pemeliharaan aset tanaman belum menghasilkan meliputi imbalan kerja yang terkait langsung dengan pembudidayaan tanaman seperti upah tenaga kerja;

b) Biaya-biaya lainnya yang terjadi di unit/kebun yang dapat diatribusikan secara langsung ke aset tanaman semusim seperti: Biaya penyiapan lahan (land clearing); Biaya handling dan pengangkutan bibit tanaman; Biaya penanaman, pemupukan, dan pemeliharaan; Biaya pengujian aset tanaman; dan, Biaya komisi profesional yang menangani aset tanaman.

3) Alokasi biaya tidak langsung. Biaya tidak langsung yang dapat dikapitalisasi ke aset tanaman semusim antara lain biaya pinjaman

b. Biaya penyisipan

1) Biaya penyisipan/sulaman suatu aset tanaman dalam areal pembibitan diakui sebagai penambah jumlah tercatat aset tanaman semusim.

2) Biaya penyisipan/sulaman suatu aset tanaman dalam areal kebun diakui sebagai beban.

3. Penyusutan aset tanaman semusim dimulai ketika bibit ditanam menjadi tanaman siap panen.

4. Jumlah penyusutan adalah sebesar jumlah yang dapat disusutkan dengan metode garis lurus tanpa dikurangi dengan nilai residu.

5. Penghentian pengakuan aset tanaman semusim dilakukan saat aset tanaman semusim diganti atau dimusnahkan, dijual atau dengan cara lainnya.

6. Biaya peroleh aset tanaman semusim diakui sebesar akumulasi biaya yang dapat dikapitalisai sampai menjadi tanaman siap panen.

7. Aset tanaman semusim diukur pada biaya perolehan dikurangi akumulasi penyusutan dan akumulasi rugi penurunan nilai.

8. Penyusutan aset tanaman semusim diakui sebagai penambah biaya perolehan persediaan yang dihasilkannya.

9. Akumulasi penyusutan aset tanaman semusim disajikan sebagai pos pengurang jumlah tercatatnya.

10. Aset tanaman semusim disajikan dalam kelompok aset tidak lancar.

11. Hal-hal yang harus diungkapkan antara lain:

a. Rincian jenis dan jumlah aset tanaman semusim yaitu aset tanaman pembibitan;

b. Dasar penilaian yang digunakan untuk menentukan jumlah bruto aset tanaman semusim;

c. Metode penyusutan yang digunakan;

d. Umur manfaat atau tarif penyusutan yang digunakan;

e. Jumlah tercatat bruto dan akumulasi penyusutan awal dan akhir periode;

f. Rekonsiliasi jumlah tercatat awal dan akhir periode yang menunjukkan: 


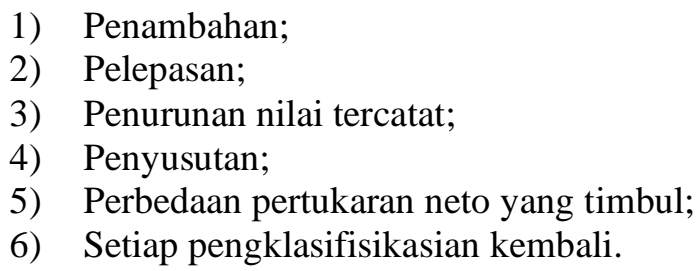

\section{Ilustrasi Jurnal}

1. Pada saat perolehan
Db. Aset tanaman semusim
Kr. Beban impor
$\mathrm{Kr}$. Beban tenaga kerja langsung/pos beban langsung lainnya
$\mathrm{Kr}$. Beban bunga yang dikapitalisasi

2. Penyusutan

Db. Beban penyusutan-aset tanaman semusim

Kr. Akumulasi penyusutan- aset tanaman semusim

3. Penurunan nilai

(beban penyusutan akan menjadi biaya perolehan persediaan)

Db. Kerugian penurunan nilai (beban non usaha)

Kr. Akumulasi penurunan nilai- aset tanaman semusim

4. Penghentian pengakuan

Db. Akumulasi penyusutan

Kr. Akumulasi penyusutan nilai- aset tanaman semusim

Kr. Aset tanaman semusim

Aset tidak lancar lainnya yang berhubungan langsung dengan kelapa sawit adalah Aset tanaman tahunan. Aset tanaman tahunan adalah aset tanaman perkebunan yang terdiri dari tanaman belum menghasilkan (TBM) dan tanaman telah menghasilkan (TM). Aset tanaman tahunan dapat dibedakan menjadi:

1. Tanaman belum menghasilkan (TBM);

2. Tanaman telah menghasilkan (TM).

Proses yang dilalui menjadi untuk aset tanaman tahunan adalah:

1. Dari pembibitan sampai dengan menjadi tanaman telah menghasilkan (proses dari TBM menjadi TM).

2. Dari tanaman telah menghasilkan sampai dengan dihentikan pengakuannya, misalnya ditebang atau diganti dengan tanaman lain.

Biaya perolehan awal aset tanaman tahunan antara lain:

1. Biaya yang diakui sebagai bagian dari TBM (biaya perolehan awal), yaitu:

a. Biaya input, adalah harga perolehan bibit dan biaya lainnya yang dikeluarkan entitas sampai dengan bibit siap tanam.

b. Biaya proses, adalah biaya-biaya yang dikeluarkan setelah biaya input sampai menjadi bibit tanaman berikutnya yang terdiri dari:

1) Biaya tenaga kerja langsung diunit/kebun untuk pemeliharaan aset tanaman belum menghasilkan meliputi imbalan kerja yang terkait langsung dengan pembudidayaan tanaman seperti upah tenaga kerja.

2) Biaya-biaya lainnya yang terjadi diunit/kebun yang dapat diatribusikan secara langsung ke aset tanaman tahunan seperti:

a) Biaya penyiapan lahan (land clearing);

b) Biaya handling dan pengangkutan bibit tanaman;

c) Biaya penanaman, pemupukan, dan pemeliharaan;

d) Biaya pengujian aset tanaman tahunan apakah aset berfungsi dengan baik, setelah dikurangi hasil bersih penjualan produk yang dihasilkan sehubungan dengan pengujian tersebut;

e) Biaya komisi profesional yang menangani aset tanaman.

c. Alokasi biaya tidak langsung

2. Penjualan hasil tanaman selama TBM diakui sebagai pendapatan usaha: 
3. Biaya penyisipan

a. Pendekatan areal

1) Biaya penyisipan suatu aset tanaman dalam areal TBM diakui sebagai penambah jumlah tercatat aset TBM.

2) Biaya penyisipan suatu aset tanaman dalam areal TBM diakui sebagai beban periode terjadinya.

b. Pendekatan per pohon

1) Jumlah tercatat aset tanaman TM yang diganti diakui sebagai beban periode terjadinya.

2) Biaya aset tanaman baru diakui sebagai biaya perolehan aset tanaman.

Beberapa perlakuan akuntansi pada asset tanaman tahunan ini adalah;

1. TBM direklasifikasi ke TM pada saat tanaman menghasilkan.mPenentuan waktu tanaman dapat menghasilkan ditentukan oleh:
a. Pertumbuhan vegetatif; dan
b. Berdasarkan taksiran manajemen.

2. Setelah menjadi TM

a. Biaya perolehan TM sebesar nilai tercatat TBM yang direklasifikasi ke TM.

b. Biaya-biaya yang terjadi setelah TM diakui sebagai beban periode terjadinya, kecuali biaya-biaya yang memenuhi syarat untuk dikapitalisasi ke aset.

c. Biaya-biaya yang dikeluarkan untuk memelihara aset tanaman yang tidak menambah manfaat ekonomis aset tanaman, atau biaya-biaya yang mengembalikan aset tanaman ke kondisi normalnya, maka biaya-biaya tersebut dibebankan pada periode terjadinya. Misalnya, biaya pemupukan rutin.

3. Penyusutan aset tanaman dimulai ketika TBM direklasifikasi ke TM. Penyusutan dilakukan menggunakan metode garis lurus dengan taksiran umur manfaat selama 25 tahun untuk kelapa sawit. Jumlah yang dapat disusutkan yaitu biaya perolehan dikurangi nilai residu.

4. Penghentian pengakuan aset tanaman tahunan dilakukan saat aset tanaman semusim diganti atau dimusnahkan, dijual atau dengan cara lainnya.

5. Pengakuan dan pengukuran awal (TBM dan TM)

a. Biaya perolehan TBM sebesar akumulasi biaya yang dikapitalisasi ke TBM tersebut.

b. Biaya perolehan TM sebesar nilai tercatat TBM yang direklasifikasi ke TM.

6. Pengukuran selanjutnya (TBM dan TM)

a. TBM diukur pada biaya perolehan setelah dikurangi akumulasi rugi penurunan nilai.

b. TM diukur pada biaya perolehan setelah dikurangi akumulasi penyusutan dan akumulasi rugi penurunan nilai.

7. Penyusutan (TM)

a. Penyusutan aset tanaman tahunan diakui sebagai penambah biaya perolehan persediaan yang dihasilkannya.

b. Akumulasi penyusutan aset tanaman disajikan sebagai pos pengurang jumlah tercatatnya.

8. Penghentian pengakuan

a. Keuntungan atau kerugian dari penghentian pengakuan diakui pada periode terjadinya.

b. Keuntungan atau kerugian tersebut disajikan sebagai pendapatan atau beban non usaha.

9. Hal-hal yang harus diungkapkan antara lain:

a. Rincian jenis dan jumlah aset tanaman tahunan yaitu aset tanaman pembibitan;

b. Dasar penilaian yang digunakan untuk menentukan jumlah bruto aset tanaman tahunan;

c. Metode penyusutan yang digunakan;

d. Umur manfaat atau tarif penyusutan yang digunakan ;

e. Jumlah tercatat bruto dan akumulasi penyusutan awal dan akhir periode;

f. Rekonsiliasi jumlah tercatat awal dan akhir periode yang menunjukkan:

1) Penambahan;

2) Pelepasan;

3) Penurunan nilai tercatat;

4) Penyusutan;

5) Perbedaan pertukaran neto yang timbul;

6) Setiap pengklasifisikasian kembali.

\section{Ilustrasi Jurnal}


1. Pada saat perolehan

a. Aset tanaman TBM

Db. Aset tanaman TBM

Kr. Beban input

Kr. Beban tenaga kerja langsung/pos beban langsung lainnya

$\mathrm{Kr}$. Beban bunga yang dikapitalisasi

b. Reklasifikasi aset tanaman TBM menjadi TM

Db. Aset tanaman TM

Kr. Aset tanaman TBM

2. Penyusutan

Db. Beban penyusutan - aset tanaman TM

Kr. Akumulasi penyusutan - aset tanaman TM

(beban penyusutan akan menjadi biaya perolehan persediaan)

3. Penurunan nlai

Db. Kerugian penurunan nilai (beban nonusaha).

$\mathrm{Kr}$. Akumulasi penurunan nilai.

4. Pemulihan nilai

Db. Akumulasi rugi penurunan nilai

Kr. Keuntungan pemulihan nilai (pendapatan non usaha)

5. Penghentian pengakuan

Db. Akumulasi penyusunn- aset tanaman TM.

Kr. Aset-aset tanaman TM.

Setelah mengikuti sosialisasi penyajian laporan keuangan tersebut, dari 30 orang peserta hanya 7 peserta yang bersedia untuk terlibat dalam kegiatan pelatihan dan pendampingan lanjutan. Tidak cukup banyaknya jumlah peserta peserta yang ikut dalam kegiatan selanjutnya didasarkan pada alasan utama, tidak akan mampunya mereka menguasai pelaporan tersebut yang menurut mereka sudah terlanjur rumit. Alasan lainnya adalah tidak ada waktu dan belum membutuhkan.

Tabel 1. Tabulasi Mitra Pengabdian Setelah Sosialisasi Pelaporan Keuangan menggunakan pendekatan Asset Biologis

\begin{tabular}{lc}
\hline \multicolumn{1}{c}{ Keterangan } & Jumlah \\
\hline Jumlah peserta sosialisasi Pelaporan Keuangan & 30 \\
Jumlah peserta yang tidak bersedia untuk mengikuti kegiatan pelatihan dan & 23 \\
pendampingan & \\
Jumlah peserta mitra final yang ikut dalam pelatihan dan pengabdian & 7 \\
\hline
\end{tabular}

Tabel 2. Nama Peserta Mitra

\begin{tabular}{ccc}
\hline No. & Nama & Umur \\
\hline 1 & Suyanto & 42 \\
2 & Misbah & 38 \\
3 & Muji Hartoyo & 45 \\
4 & Suwarno & 42 \\
5 & Sri Marsiam & 36 \\
6 & Eka Elisa Putri & 35 \\
7 & Lupita Sari & 28 \\
\hline
\end{tabular}




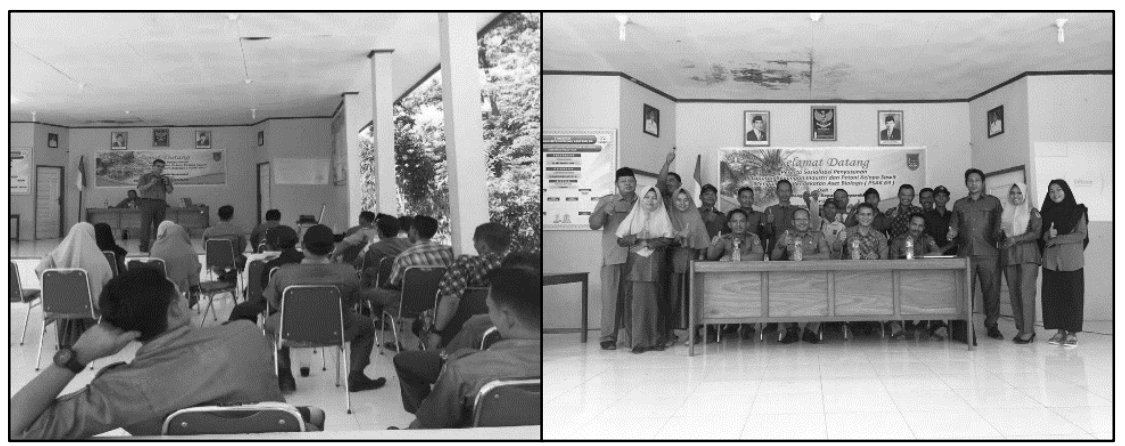

Gambar 4. Sosialisasi Kegiatan Penyusunan Laporan Keuangan Aset Biologis Industri Kelapa Sawit

Pendampingan dilakukan sebanyak 3 kali secara langsung dan juga pendampingan tidak langsung dengan media telp langsung, jika mereka tidak memahami atau kesulitan memahami implementasi transaksi mereka dalam laporan keuangan.
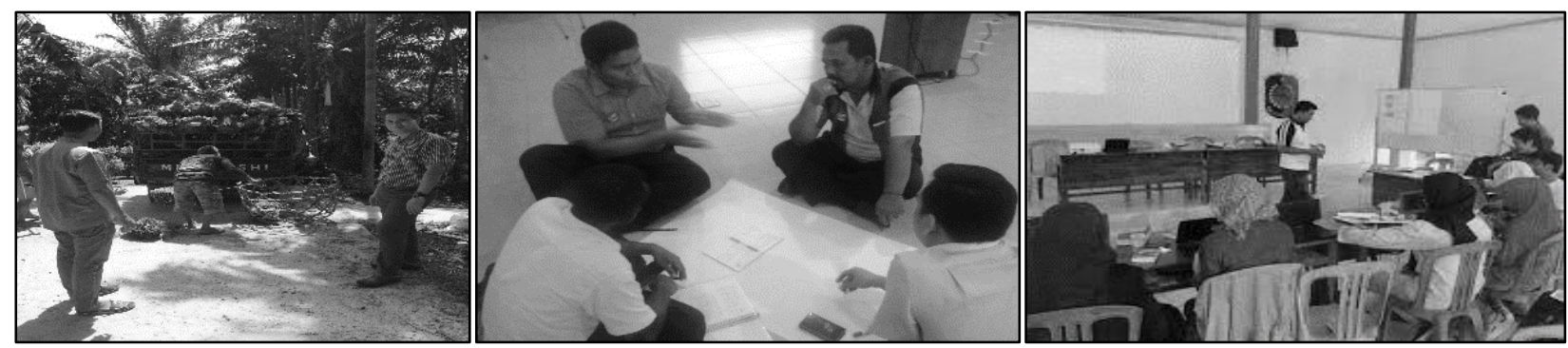

Gambar 5. Pelatihan dan Pendampingan Mitra

\begin{tabular}{|c|c|c|c|}
\hline \multicolumn{4}{|c|}{$\begin{array}{c}\text { Perkebunan Sawit Bapak Suwarno } \\
\text { Laporan Posisi Keuangan } \\
\text { Per } 2 \text { Juni } 2019\end{array}$} \\
\hline Harta & & Kewajiban & \\
\hline Harta Lancar & & Hutang Bank & 40.000 .000 \\
\hline Kas & 2.500 .000 & & \\
\hline Bank & 12.500 .000 & & \\
\hline \multirow[t]{2}{*}{ Persediaan Bibit } & 5.500 .000 & & \\
\hline & 20.500 .000 & & \\
\hline Harta Tidak Lancar & & Modal & \\
\hline Tanah & 60.000 .000 & Modal Perorangan & 100.500 .000 \\
\hline Tanaman Belum Menghasilkan & & & \\
\hline \multirow[t]{2}{*}{ Tanaman Telah Menghasilkan } & 60.000 .000 & & \\
\hline & 120.000 .000 & & \\
\hline Total Harta & 140.500 .000 & Total Hutang + Modal & 140.500 .000 \\
\hline
\end{tabular}

Gambar 6. Contoh Laporan Keuangan sederhana Industri Kelapa Sawit UMKM Mitra

Dalam kegiatan pengabdian tesebut, kesulitan mitra untuk menguasai Akuntansi dengan pendekatan asset biologis berasal dari tidak memadainya pemahaman akuntansi itu sendiri secara umum. Sehingga sangat membutuhkan waktu yang lebih lama dan intensif dalam mempersiapkan UMKM untuk dapat menyusun laporan keuangan industry kelapa sawit dengan menggunakan pendekatan asset biologis secara menyeluruh. Namun dari evaluasi yang dilakukan menunjukkan bahwa empat orang diantara mitra dapat memahami konsep penyusunan laporan keuangan industri kelapa sawit menggunakan pendekatan asset biologis, dua diantaranya memiliki tingkat pemahaman terbaik dan dua lainnya dengan tingkat pemahaman sedang. Evaluasi dilakukan dengan mengamati pekerjaan dan diskusi dengan mitra. 


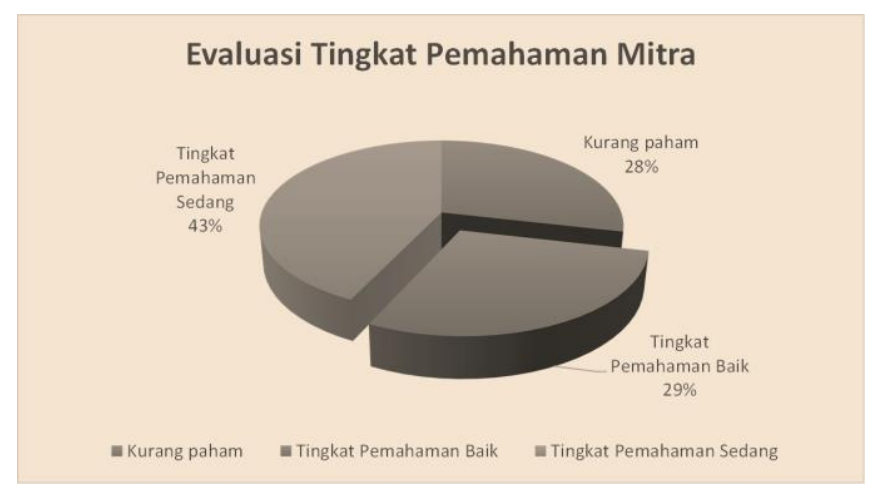

Gambar 6. Evaluasi Tingkat Pemahaman Mitra

\section{KESIMPULAN}

Kegiatan pengabdian untuk membumikan penyusunan laporan keuangan dengan menggunakan pendekatan asset biologis ini dinilai memang tidak mudah dilakukan mengingat terbatasnya pengetahuan dasar akuntansi umum pada objek pengabdian. Sehingga dalam menyusun Laporan Keuangan dengan menggunakan pendekatan asset biologis menjadi lebih sulit untuk kasus industri perkebunan kelapa sawit. Namun dengan pengenalan awal, pelatihan dan pendampingan pola tersebut diyakini akan mampu meningkatkan keterampilan manajemen UMKM dalam menyusun laporan keuangan dengan menggunakan pendekatan asset biologis. Hal tersebut dibuktikan dengan tingkat pencapaian hasil yang mencapai $72 \%$, dengan tingkat pemahaman baik dan sedang berdasarkan evaluasi pekerjaan dan diskusi yang dilakukan.

Peserta sosialisasi dan mitra pengabdian umumnya mengakui arti pentingnya penyusunan laporan keuangan yang telah diberikan. Namun mengingat keterbatasan waktu yang tersedia dan daya serap UMKM mitra, maka proses diseminasi pengetahuan dan keterampilan penyusunan laporan keuangan tersebut tidak mudah.

Hasil evaluasi yang dilakukan menunjukkan bahwa target yang ingin dicapai dari kegiatan pengabdian tersebut tercapai berdasarkan prosentase pemahaman mitra yang terlibat. Guna memperluas konsekwensi positif dari kegiatan ini, maka sangat diperlukan kegiatan yang sama dengan waktu dan ketersediaan dana yang lebih besar, agar proses diseminasi, pelatihan dan pendampingan menjadi lebih efektif.

\section{DAFTAR PUSTAKA}

Argiles, J., \& E. Slof. 2001. New Opportunities for Farm Accounting. The European Accounting Review 102.

Binus. 2014. Status Konvergensi IFRS-PSAK. http://www.accounting.binus.ac.id

Farida, I. 2015. Analisis Perlakukan Akuntansi Aset Biologis Berdasarkan International Accounting Standard 41 Pada PT. Perkebunan Nusantara VII (Persero), http://www.eJournal.unesa.ac.id Article

Gamayuni, R. R. 2009. Perkembangan Standar Akuntansi Keuangan Indonesia Menuju International Financial Standars. Jurnal Akuntansi dan Keuangan 14(2).

Laux, C., \& C. Leuz. 2009. The crisis of fair-value accounting: Making sense of the recent debate. Accounting, Organisations and Society 34: 6-7.

Maruli, S. 2010. Analisis Pendekatan Nilai Wajar dan Nilai Historis dalam Peniaian Asset Biologis pada Perusahaan Agricultur: Tinjauan Kritis Rencana Adopsi IAS 41. Purwokerto: SNA 13.

Kurniawati, H. 2013. Tinjauan Rencana Adopsi IAS 41 Pada Perusahaan Agrikultur di Bursa Efek Indonesia. Binus Busineness Review 4(1).

Sinaga, R. U. 2014. Up Date Konvergensi IFRS di Indonesia, dipresentasikan di Plaza Bapindo, Mandiri Tower, Jakarta, 13 Maret 2014.

Situmorang, M. A., dan A. Purwanto. 2011. Transisi Menuju IFRS dan Dampaknya terhadap Laporan Keuangan (Studi Empiris pada Perusahaan yang Listing di BEI), Skripsi, Universitas Diponegoro.

Svensson, A., A. Nylen, \& A. Gunnevik. 2008. The Swedish Forest Industry s Application of the IAS $41-$ Agriculture. Master's Thesis, Stockholm School of Economics.

Direktorat Jenderal Perkebunan. 2016. Statistik Perkebunan Indonesia 2015-2017 Kelapa Sawit

IASC. 2001. International Accounting Standard 41: Agriculture. International Accounting Standards 
IAI. 2015. Standar Akuntansi Keuangan.

Pusat Data dan Informasi Pertanian-Sekertariat Jenderal Kementrian Pertanian. 2016. Outlook Kelapa Sawit Komoditas Pertanian, Subsektor Perkebunan. 